\title{
STUDENTS WITH VISUAL IMPAIRMENTS: BRAILLE
} READING RATE

Dr. Daniela Dimitrova Radojichikj, University Ss. Cyril and Methodius, Faculty of Philosophy, Department of Special Education and Rehabilitation, Skopje, Republic of Macedonia E-mail: daniela@fzf.ukim.edu.mk

Received: February, 25.2015. Accepted: Aprl, 06.2015.

\begin{abstract}
A comparison reading performance was done between 8 students who are using Braille and 14 students who are using enlarged print to read. Reading performance was determined using reading rate (words per minute, wpm). Reading rate results showed no significant difference $(\mathrm{p}>0.05)$ between those using the Braille $(16.62 \pm 11.61 \mathrm{wpm})$ and those using the enlarged print (27.21 $\pm 24.89 \mathrm{wpm})$. This study has shown that Braille reader students read at lower reading rate compared to print reader students with visual impairment.
\end{abstract}

Keywords: Students with visual impairment, Reading, Braille reading rate, Braille literacy.

\section{INTRODUCTION}

Reading is essential in the context of education. Education is generally understood to encompass literacy, defined as "the ability to read and write" (Concise Oxford Dictionary, 2009). For individuals who do not have easy access to print materials because they are visually impaired (that is, those who are blind or have low vision) this process of acquiring knowledge through reading requires additional effort and accommodations. Braille literacy is of critical importance to the achievement of independence and employability of those who are blind or visually impaired (Ryles, 1996).

Globally, Braille was and still is the primary reading method for blind people to access information and education independently. Braille is a tactile writing system, where each character is represented by a combination of one to six raised dots. A dot may be raised at any of the six positions to form 64 possible subsets. Differently from visual

Corresponding Author

Dr. Daniela Dimitrova Radojichikj

University Ss. Cyril and Methodius, Faculty of Philosophy, Department of Special Education and Rehabilitation, Skopje, Macedonia

E-mail: daniela@fzf.ukim.edu.mk processing, which enables simultaneous and parallel perception of text, the tactile modality offers a successive input and imposes a sequential nature of reading (Pring, 1984).

\section{Reading Braille}

There is no uniformed way of reading Braille. Good Braille reading is characterized by fluid movement across the page. New Braille learners face the difficulty of combining body postures with spatial and tactile tasks, often becoming confused about keeping their hands on the same line and losing their position (McLinden and McCall 2002). Wormsley (1979) divided hand movement patterns into two major categories: one-handed and twohanded reading. Proficient readers of Braille typically read with two hands, starting the line with the left hand and finishing it with the right (Whittle, 2005). The most commonly taught technique is to use all four fingers of both hands side by side along a single line. Even though the focus is still placed on one Braille cell contacted with one finger, the use of the eight fingers provides spatial awareness of the line being read and it is supposed to make reading quicker and more efficient (Miller 1997).

It has been noted that reading speeds among early Braille readers, whether they were children or adults recently visually impaired, are often considerably slower than those of their print reading peers. The time for the identification of a word includes the precise time needed to perceive each letter that forms a word plus the necessary time to in-tegrate this previously stored information and thus identify a whole word. This double process explains the reduced reading speed rates shown by Braille readers. In the case of Braille reading, tactile fixations are in use, which cannot be compared to visual fixations, since tactile reading involves fingers, hands, 
and arms. Moreover, whereas ocular movements allow sighted persons to skip some of the words of the text (although there is some fixation on most of them), people who are visually impaired cannot do the same; their fingers must necessarily pass over all the characters on a line (Simon and Huertas 1998).

In a study comparing the reading rate (speeds) of blind and seeing adults "the average print-reading rate ranged from $30 \%$ (oral reading) to $60 \%$ (silent reading) faster than the average Braille-reading rate for the various reading tasks" (Wetzel and Knowlton, 2000). On average, Braille readers read at about half the speed of print readers, at about 150 words per minute (Pring, 1984). Earlier research, also demonstrated that Braille reading rates are not constant, but vary widely, depend on the purpose of the reading task (Knowlton and Wetzel, 1996). Further research demonstrated that Braille and print reading rates varied in a parallel manner, with the Braille rates always slower than the print rates, but affected to a similar degree by the task (Wetzel and Knowlton, 2000). The disparity between the reading rates of sighted students and students with low vision increases as students' progress to middle school and high school (Corn et al., 2002).

Critical factors for the development of Braille literacy skills

Previous research indicated that the age at which Braille is learned may affect the speed at which Braille is processed (Mousty and Bertelson, 1985); that is, children who were taught Braille before the age of 10 generally became faster readers.

The lack of tactual acuity is a problem faced by students learning to read through Braille and contributes to slow reading times compared to other print readers. However, through experience and training, most visually impaired students can overcome this problem.

Instructional strategies have been identified that can increase the reading rates of students with visual impairments. From the available literature, it is readily understood that the daily instruction ranging from one to two hours is critical for the development of Braille literacy skills (Corn and Koenig, 2002). Also, the research has shown that visually impaired students are at risk of advancing in school with poor, fragmented Braille skills if they have not had high-quality instruction during their elementary school years (Koenig and Holbrook, 2000). Therefore, continued intensive instruction in writing and reading from a teacher who knows Braille is required throughout the elementary school years (Emerson et al., 2009).

The purpose of the study presented here was to measure Braille reading rate, and to compare it with reading speed of visually impaired students who use enlarged print. The second objective was to analyze the opinion of special educators about factors which may influence on Braille literacy of students with visual impairment.

\section{MATERIALS AND METHODS}

\section{Participants}

The survey was conducted on a sample composed of 22 students and 5 special educators from public school for rehabilitation of children and young people with visual impairment "Dimitar Vlahov" in Skopje, Republic of Macedonia. A total of $8(36 \%)$ Braille readers were tested, as well as $14(64 \%)$ visually impaired readers who use en-larged print for the control group. The aver-age age of the Braille readers was $13.16+1.47$ years (ranged from 11 to 15), while the average age of print readers was $11.5+2.22$ years (ranged from 9 to 16$)$. There were $15(68 \%)$ females and 7 $(32 \%)$ males.

\section{Materials and procedure}

Reading performance was determined using reading rate (words per minute, wpm). Reading speed of Braille and print readers was measured using short unfamiliar story from the textbook for first grade, consisting of 40 words. The print size of the text varies depending on the students near acuity. The print size chosen for each student was one size bigger than the near acuity. This is to make sure that vision is not a factor that causes slower reading rate. The same texts that have been converted to Braille format were used for Braille reader. The decision of which hand and which fingers to use for reading and the reading method was left to the student. The participants were allowed to explore the text briefly before reading. Than, the students were asked to read aloud (oral reading) and the reading time as well as the number of errors was recorded. The words that were missed or read incorrectly were counted as error. From these data, reading rate was computed in words per minute (wpm). 
A significant role for special educators is to address their students' slow reading rates and attitudinal barriers through the use of appropriate instructional strategies. For that reason, five special educators were asked to state which activity they use for enhancing the learning of Braille among students with visual impairment.

\section{RESULTS}

The reading rate of the students who are using Braille and print to read is shown in Figure 1. It can be noticed that most of the Braille readers have lower reading rate compared to the print readers. The range of reading rate for the Braille readers is from 7 to 30 wpm with mean $16.62 \pm 11.61 \mathrm{wpm}$. The reading rate for print readers is from 4 to $83 \mathrm{wpm}$ with mean $27.21 \pm 24.89 \mathrm{wpm}$. The two sample test shows that the difference in the reading rate between Braille and print readers is not significant $(t=1.354 ; p>0.05)$.

Figure 1. Braille and print reading rate

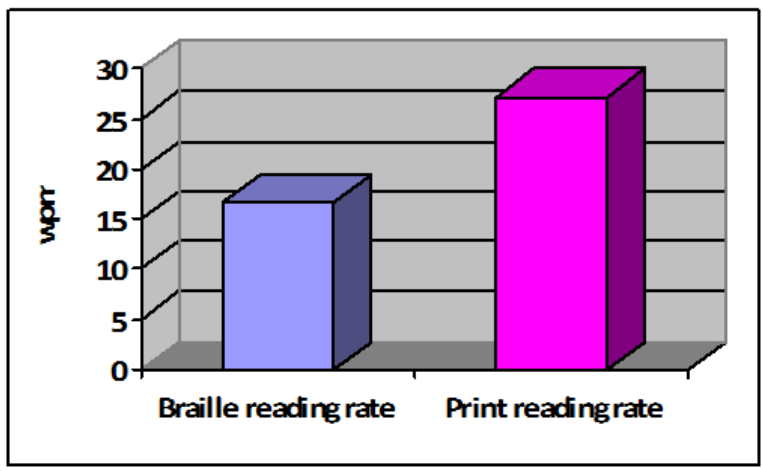

On the first question: For which school subject you have books converted to Braille format, the answer of the special educators are presented on Table 1.

Table 1. School books converted to Braille

\begin{tabular}{lccccc}
\hline \multicolumn{1}{c}{$\begin{array}{c}\text { School } \\
\text { subject }\end{array}$} & \multicolumn{5}{c}{ Grade } \\
\cline { 2 - 6 } $\begin{array}{l}\text { Macedonian } \\
\text { language }\end{array}$ & yes & yes & yes & $/$ & $/$ \\
\hline Mathematic & $/$ & $/$ & $/$ & $/$ & $/$ \\
\hline Nature & $/$ & yes & $/$ & yes & $/$ \\
\hline Society & $/$ & yes & $/$ & yes & $/$ \\
\hline Music & $/$ & $/$ & $/$ & $/$ & $/$
\end{tabular}

Although the school has a total of 341 Braille books, most of them are not used because they are old and not in line with the new school curriculum. Unfortunately, the school has no Braille books for all subjects (Table 1).
According the answer of special educators, students overcome Braille letter at:

- Second grade (2 special educators) and

- Third grade (3 special educators).

Special educators' opinions about the way they can enhance the learning of Braille alphabet among students with visual impairment are displayed in Table 2 .

Table 2. Enhancing the learning of Braille

\begin{tabular}{ll}
\hline Activity & $\mathrm{N}$ \\
\hline Exercises for development of fine & $4 \mathrm{SE}^{*}$ \\
motor skills of hands & \\
\hline Individual work with student & $2 \mathrm{SE}^{*}$ \\
\hline Using Braille literature & $5 \mathrm{SE}^{*}$ \\
\hline Additional teaching hours & $1 \mathrm{SE}^{*}$
\end{tabular}

\section{DISCUSSION}

Individuals tend to read Braille at a slower rate than print readers read print (Emerson et al., 2009; Wetzel and Knowlton, 2000). In this study, it was found that most of the students who are using Braille, read at a much lower speed compared to those who are using print. But, this finding differs from a previous study by Legge et al. (1999) who showed that the Braille and print readers have comparable reading rate. Also, according to Erin (2003), rapid Braille readers can decode as quickly as print readers.

The mean reading rate of Braille and print readers found in this study is much lower than those reported in the past. For example, in the 1960s, Lowenfeld, Abel and Hatlen (1969) found that typical rates of Braille reading were $84 \mathrm{wpm}$ in local schools and 72 wpm in residential schools fourth-grade and $149 \mathrm{wpm}$ and $116 \mathrm{wpm}$ in local and residential schools, respectively, in the eighth grade. Foulke (1991) found that the mean Braille reading rate for adults is about $100 \mathrm{wpm}$. Research investigating the reading rates of expert adult Braille readers reported a mean oral reading rate of 135.9 wpm (Wetzel and Knowlton, 2000). In another study, Wolffe (2000) stated that for any job in which literacy is used; a minimum reading rate of 150 words per minute (wpm) should be expected. Various studies have found that Braille readers do not acquire reading rates that meet Wolffe (2000) estimate.

Legge et al. (1999) found that context can increase the reading rate up to $40 \%$. Like 
most study in the past, this study used related sentences to measure the reading speed. So, the reason of lower reading speed is not the text that was used in this research.

Hasbrouck and Tindal (2006) studied oral reading fluency and developed a baseline to help teachers identify students needing spe-cific instruction to improve oral reading flu-ency.

Perceptual factors limiting Braille reading speed are poorly understood, partly because of the lack of accurate, standardized testing methods. The lack of tactual acuity is a problem faced by people learning to read through Braille and contributes to slow reading times compared to other print read-ers. However, by experience and training, most visually impaired children can over-come this problem. In this study, four of five special educators indicate that the "exercise for developing fine motor skills of hand" can enhance the learning of Braille alphabet.

Teachers often accommodate their students' lower reading rates by reducing assignments or providing auditory alternatives. The reading speed of Braille readers and those who access printed material can be improved by daily reading practices and repeated-reading strategy. In this study, only one from five special educators thinks that "additional teaching hours" can enhance the learning of Braille.

Although the legislation in some countries supports people with visual impairment to have access to materials in their preferred format, e.g. the availability of Braille material is affected by the extra expense that the production of Braille books may incur. The situation in our country is not good because the available Braille books are restricted only to few school subjects.

\section{CONCLUSION}

The risk of poor academic performance and the potential for frustration that is associated with slow reading speed has been a topic of concern for students with visual impairment for more than a decade (Corn et al., 2002). Although most of the studies about Braille reading rate had many drawbacks, they all indicate that students' reading performance was poor for competing in academic classes and for future employability. These measures can help teachers determine each student's individual needs, so as to adjust the instructional program accordingly (Lusk and Corn, 2006).
Reading and learning to read Braille is often slower than reading print and specific skills must be learnt. Reading Braille can be hindered by several factors. Early intervention and the introduction of tactual discrimination exercises can help overcome many problems associated with learning to read Braille, developing children's touching skills and making it easier to identify Braille cells.

Low reading rates affect students' perfor-mance and can result in greater frustration and less time spent reading (Carver, 1990).

\section{Conflict of interests}

Author declare no conflict of interest.

\section{REFERENCES}

Bell, J., Corn, A., Jose, R., Perez, A., Wall, R., \& Wilcox, K. (2002). An initial study of reading and comprehension rates for students who received optical devices. Journal of Visual Impairment \& Blindness (JVIB), 96(05).

Carver, R. P. (1990). Reading rate: A review of research and theory. Academic Press.

Concise Oxford Dictionary Online, s. v. "Literacy." Retrieved from http://www.askoxford.com

Corn, A., \& Koenig, A. (2002). Literacy for students with low vision: A framework for delivering instruction. Journal of Visual Impairment \& Blindness (JVIB), 96(05).

Emerson, R. W., Holbrook, M. C., \& D’Andrea, F. M. (2009). Acquisition of literacy skills by young children who are blind: Results from the ABC Braille Study. Journal of Visual Impairment \& Blindness, 103(10), 610-624.

Erin, J. N. (2003). Educating students with visual impairments. Arlington, VA: The Council for Exceptional Children.

Foulke, E. (1991). Braille. In Heller, M. A., \& Schiff, W. (Eds.). (2013). The psychology of touch. Psychology Press. Hillsdale, NJ: Erlbaum.

Hasbrouck, J., \& Tindal, G. A. (2006). Oral reading fluency norms: A valuable assessment tool for reading teachers. The Reading Teacher, 59(7), 636-644.

Hermelin, B., O'Connor, N. (1971). Right and lefthanded reading of Braille. Nature, 231, 470.

Knowlton, M., \& Wetzel, R. (1996). Braille reading rates as a function of reading tasks. Journal of Visual impairment and Blindness, 90, 227-236.

Koenig, A. (2000). Ensuring high-quality instruction for students in braille literacy programs. Journal of Visual Impairment \& Blindness (JVIB), 94(11).

Legge, G. E., Madison, C. M., \& Mansfield, J. S. (1999). Measuring Braille reading speed with 
the MNREAD test. Visual Impairment Research, 1(3), 131-145.

Lowenfeld, B., Abel, G. L., Hatlen, P. H. (1969). Blind children learn to read. Springfield, IL: Charles C Thomas.

Lusk, K. E., \& Corn, A. L. (2006). Learning and Using Print and Braille: A Study of Dual-Media Learners, Part 2. Journal of Visual Impairment \& Blindness, 100(11), 653-665.

McLinden, M., \& McCall, S. (2002). Learning Through Touch: Supporting children with visual impairment and additional difficulties. David Fulton Publishers.

Miller, S. (1997). Reading through Touch. London: Routledge. Pring, L. (1984). A comparison of the word recognition processes of blind and sighted children. Child Development, 1865-1877.

Mousty, P., \& Bertelson, P. (1985). A study of braille reading: 1. Reading speed as a function of hand usage and context. The Quarterly Journal of Experimental Psychology, 37(2), 217-233.

Pring, L. (1994). Touch and go: learning to read Braille. Reading Research Quarterly, 67-74.

Ryles, R. (1996). The impact of braille reading skills on employment, income, education, and reading habits. Journal of Visual Impairment and Blindness, 90, 219-226.

Simon, C., \& Huertas, J. A. (1998). How blind readers perceive and gather information written in braille. Journal of Visual Impairment and Blindness, 92, 322-330.

Wetzel, R., \& Knowlton, M. (2000). A comparison of print and braille reading rates on three reading tasks. Journal of Visual Impairment and Blindness, 94(3), 146-154.

Whittle J. (2005). Building Braille reading speed: Some helpful suggestions. National Federation for the Blind Nebraska. Retrieved from http://www. ne.nfb.org/node/562

Wolffe, K. (2000). Making it! Successful transition competencies for youth with visual disabilities. See/Hear, 5(2), 19-24.

Wormsley, D. P. (1979). The effects of a hand movement training program on the hand movements and reading rates of young braille readers. Doctoral dissertation, University of Pittsburgh. 
(IJCRSEE) International Journal of Cognitive Research in Science, Engineering and Education Vol. 3, No.1, 2015. 